\title{
Stability of Flour Mixture under Various Storage Conditions with Addition of Fenugreek Seed Powder
}

\author{
Lyudmila V. Anisimova \\ Department of Grain Storage and Processing Technology \\ Polzunov Altai State Technical University \\ Barnaul, Russia \\ anislv@mail.ru
}

\author{
Osama I. A. Soltan \\ PhD Student, Altai State Technical University \\ Department of Food Science \\ Minia University \\ El-Minia, Egypt \\ Usama.soultan@mu.edu.eg
}

\begin{abstract}
This paper investigates storage stability (165-day period) of whole oat flour obtained by hydrothermal treatment and stored at $\mathbf{4 0}$ degrees Celsius in cloth bags and flour mixture containing 66.7 percent of whole oat flour obtained by hydrothermal treatment, 13.3 percent of fenugreek seed powder, 6 percent of dry gluten, and 14 percent of wheat flour stored at 20 and 40 degrees Celsius in various types of bags (namely, cloth and plastic). Measurement of moisture content, acidity, acidity of flour by water-alcohol extraction, an acid number of fat as well as microbiological load was carried out during the storage period. The results revealed that at all storage conditions with the increase of storage time flour acidity, acidity of flour by wateralcohol extraction, and an acid number of fat increased, whereas microbiological load decreased. Changes in moisture content of stored samples are affected by various temperatures and in different types of bags. However, flour mixture stored at 20 degrees Celsius remained shelf stable over the time storage period. Whole oat flour stored at 40 degrees Celsius in cloth bags showed larger increase in the acidity, acidity of flour by wateralcohol extraction, and an acid number of fat. Flour mixture containing fenugreek seed powder and stored in plastic bags saw lower increase in acidity and an acid number of fat than the flour mixture in cloth bags and whole oat flour at 40 degrees Celsius.
\end{abstract}

Keywords-whole oat flour; storage stability; fenugreek seed powder; acidity; moisture content; acid number of fat

\section{INTRODUCTION}

Oats (Avena sativa) is a grain crop grown around the world. Products processed from oats not only are the source of essential nutrients, such as starch, protein, fats, vitamins, minerals, etc., but also play an important role in the prevention of chronic diseases of diabetes, coronary heart disease, and cancer. Healthy properties of oats are attributed to the presence of a number of biologically active compounds found in different parts of the grain. One of these compounds is soluble fiber beta-glucans contained in cell walls of the endosperm [1].

Fenugreek (Trigonella foenum-graecum) was originally cultivated in South East Europe and West Asia, but now it is mainly grown in Egypt and India [2]. The fenugreek seeds are primarily used as spice for flavoring Egyptian food products and have antidiabetic, hypocholesterolemic, and galactagogue effects when added to some food like bread. Fenugreek is also considered to be a valuable source of food proteins $(70 \%)$, good quality protein $(20-25 \%)$, lysine $(5-6 \%)$, and minerals, including iron, calcium, and beta-carotene [3]. Fenugreek seed is a good source of dietary fiber as well. This fiber functional ingredient could be included in flour mixture production.

Fenugreek seed powder is aromatic and contains antibacterial and bioactive components [4]. Thus, addition of fenugreek seed powder extends shelf life of products.

To increase the consumption of staple food made from oats, we should expand their range $[5,6,7]$. Still, in some cases, the use of oat is limited due to its tendency to rancidity that causes a bitter taste and rancid smell in its by-products [8]. The development of rancidity is particularly intense in the production of unprocessed "raw" oats. Its prevention is usually achieved through the application of heat combined with high humidity required for the inactivation of endogenous lipolytic enzymes in oats $[9,10]$

During the storage period, there occurred various chemical processes, including the accumulation of free fatty acids and further peroxides, in cereal grain products. These processes develop at a tremendous rate and lead to rapid deterioration in product quality. An acid number of fat can be an indicator of biochemical changes taking place during the storage of cereal products. Fat acidity is defined as the number of milligrams of potassium hydroxide required to neutralize the free fatty acids from $100 \mathrm{~g}$ of cereal products and calculated to a moisturefree basis. Under the Codex Alimentarius, the limit of an acid number of fat $(50 \mathrm{mg} \mathrm{KOH} / 100 \mathrm{~g})$ was applied only to white flours of extraction rates up to $75 \%$.

Flour from cereal crops is generally regarded as a microbiologically safe product owing to its low humidity [11]. However, microbiological control of flour quality during its storage is necessary as it can trap microorganisms that cause food spoilage.

Therefore, the aim of this study is to investigate the effects of storage time, storage temperature, package type, and 
addition of fenugreek seed powder on the chemical changes and microbiological load of whole oat flour and flour mixture based on whole oat flour. Besides, we compared analyses of acidity, moisture content, and fat acidity as part of our study.

\section{RESEARCH METHODS}

\section{A. Materials}

Oat Samples. The oat samples (Avena sativa L.) were grown in 2017 in Altai region. The samples were carefully cleaned, treated with hydrothermal processing, and then milled by a laboratory mill 3100 (Finland) into fine powder. At the Department of Grain Storage and Processing Technology, Altai State Technical University the technology of the production of flour from oat is based on the use of hydrothermal treatment. In the experiment, the hydrothermal treatment of the oats was carried out as follows: first, the grain was moistened in a laboratory unit by adding a calculated amount of water under vacuum. Then, it was put into hermetically sealed containers for a predetermined time. Further, the grain was dried to predetermined moisture in a laboratory drier in a stream of heated air.

Wheat Flour and Fenugreek. Wheat flour samples were obtained from the local market in the city of Barnaul, Russia, whereas the fenugreek was obtained from the local market in Egypt. The fenugreek samples were carefully cleaned and then milled by a laboratory mill into fine powder.

\section{B. Storage Studies of Oat Flour}

Flour mixtures containing $66.7 \%$ of whole oat flour obtained by hydrothermal treatment, $13.3 \%$ fenugreek seed powder, $6 \%$ dry gluten, and $14 \%$ wheat flour (Fig. 1) were properly weighed (45 g each), packaged in cloth bags, closed, and stored at $20 \pm 0.5^{\circ} \mathrm{C}$ and relative humidity $65 \pm 0.1 \%$. Additionally, flour mixtures to be stored at $40 \pm 0.5^{\circ} \mathrm{C}$ were divided into two portions: the first one was packaged in cloth bags, while the second one was packaged in zip lock plastic bags. Whole oat flour in cloth bags was then closed to determine the storage stability. The temperatures and relative humidity inside the storage box were measured with a thermohygrometer before sample collection.

Moisture content, acidity, acidity of flour by water-alcohol extraction, and fat acid number of the samples were identified every 2 weeks, while the microbiological counts were done every 4 weeks of storage.

\section{Chemical Analysis}

- Moisture content was determined by using an air oven at $130^{\circ} \mathrm{C} / 40 \mathrm{~min}$ according to GOST 940488 [12].

- Acidity was determined by the calibration method according to GOST 27493-87 [13].

- Acidity of flour by water-alcohol extraction was determined by the calibration method [14].

- Acid number of fat was determined according to GOST 31700-2012 [15].

\section{Microbiological Load}

The microbiological analysis (total bacteria) of oat flour was carried out immediately after production and during its storage. Each sample (1 g) was serially diluted by dissolving in $9 \mathrm{~mL}$ of distilled water. One milliliter from each diluent was plated in Petri dish and plated out on nutritional agar plates for bacterial and fungal count. The plates were incubated at $37^{\circ} \mathrm{C}$ for $48 \mathrm{~h}$ for bacterial growth and 7 days for fungal growth [16].

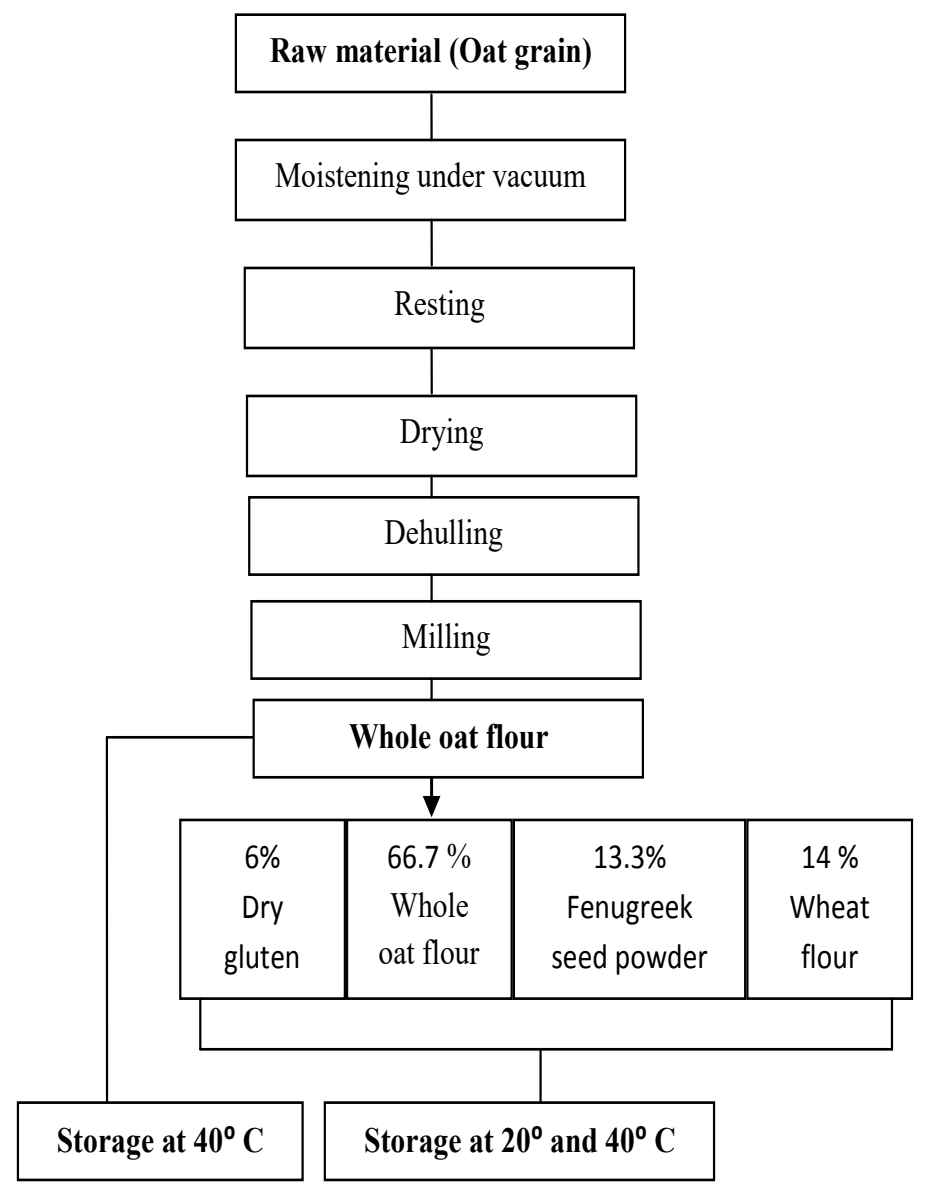

Fig. 1. Flow chart of whole oat flour obtained and mixture preparation

\section{RESULTS AND DISCUSSION}

\section{A. Moisture Content}

Fig. 2 shows moisture content of whole oat flour stored at $40^{\circ} \mathrm{C}$ in cloth bags. From these results we can see that moisture content of whole oat flour decreased during the first storage period within two months. This decrease of moisture content may be attributed to the equilibration process of the stored flour with the surroundings [17]. After that, there was a slight increase in the moisture content that later stabilized due to the equilibrium between the moisture content of flour and the relative humidity of storage environment.

Fig. 2 also demonstrates moisture content for flour mixtures. The data indicate that moisture in flour mixture rapidly increased during the first month, after that the chart 
shows a slight decrease that is followed by the increase during the second month that further on stabilizes until the end of the storage period. The increase in the moisture content of flour mixture can be attributed to the addition of fenugreek seed powder, dry wheat gluten, wheat flour and its hydrophilic compounds effect on water absorption of flour mixture [18]. Higher moisture content was indicated in flour mixture stored in cloth bags at $20^{\circ} \mathrm{C}$. However, the type of bags did not produce a significant effect on moisture content of flour mixture stored at $40{ }^{\circ} \mathrm{C}$.

\section{B. Acidity and Acidity by Water-Alcohol Extraction}

The acidity and acidity by water-alcohol extraction of grain and flour characterize their freshness. When grain and products of its processing are stored, their acidity, as a rule, increases.

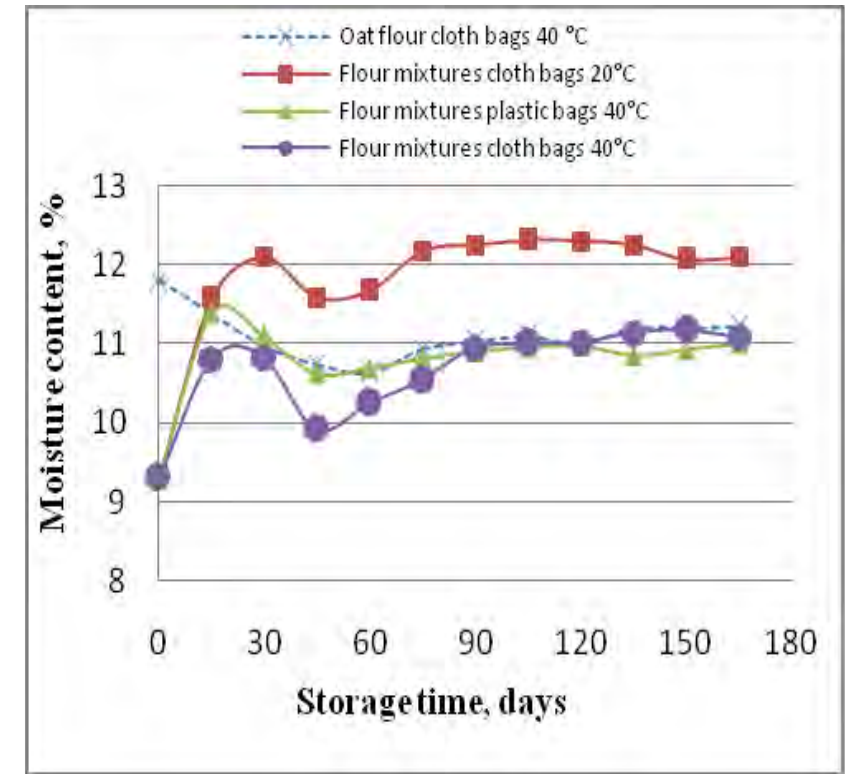

Fig. 2. Effect of storage conditions on moisture content

The increase in the acidity and acidity by water-alcohol extraction of flour is caused by the accumulation of products of hydrolytic breakdown of fats, phosphorus compounds, and carbohydrates.

Table 1 shows that in zero time the titratable acidity and acidity by water-alcohol extraction of the whole oat flour obtained from the oat grain after hydrothermal treatment rate was significantly less than the acidity of flour mixture after addition of fenugreek seed powder and dry gluten.

The lower rate of the whole oat flour acidity and acidity by water-alcohol extraction as compared to the flour mixture is accounted for the various chemical compositions of these products. At the same time, the effect of heat and moisture in the hydrothermal treatment of grain leads to partial denaturation of proteins and a decrease in the activity of enzymes that also contributes to the decrease in the acidity of oat flour.
During the storage, the acidity of all samples of whole flour and flour mixture increase may be attributed to the accumulation of linoleic and linolenic acids [19]. It is further to mention that during the whole storage period the acidity and acidity by water-alcohol extraction of the whole oat flour stored at $40^{\circ} \mathrm{C}$ in cloth bags showed higher titratable acidity and acidity by water-alcohol extraction rate as compared to the acidity of flour mixture.

The study found out that the addition of fenugreek seed powder in flour mixture results in a slight increase in the samples acidity and acidity by water-alcohol extraction under various storage conditions during the storage period. This can be explained by the ability of fenugreek seed powder to reduce the degradation of the compounds of flour mixture, such as protein, and thus to reduce its acidity - that corresponds to the results found by [20]. Obviously, the lower level of acidity and acidity by water-alcohol extraction of flour mixture stored at $20^{\circ} \mathrm{C}$ may be explained by the slight effect of temperature on degradation of chemical structure of flour mixture and the partial inactivation of enzymes.

The study also examined flour mixture stored at $40^{\circ} \mathrm{C}$ in two types of bags (cloth and plastic). The results showed that acidity and acidity by water-alcohol extraction rises at a lower rate in the samples stored in the plastic bags compared to the samples in the cloth bags. The reason is that the plastic bags reduce the exposure of oxygen to mixture samples, thus reducing the oxidation and degradation of flour mixture components that results in the reduction of the acidity and acidity by water-alcohol extraction increased during the storage period.

\section{Acid Number of Fat}

Acid number of fat is another indicator of the degree of freshness of grain and products of its processing; its increase eventually leads to the development of rancidity and food spoilage [21].

Fig. 3 shows that the rate of change in the acid number of fat in the whole oat flour stored at $40^{\circ} \mathrm{C}$ can be described as three stages. The first stage (up to 30 days) was an induction period when the rates changed slightly; the second stage was the development process (from 30 to 90 days) characterized by the significant change in biochemical parameters, while the third stage can be considered as the stage of decay (90-165 days). Increase in the acid number of fat during the storage might be attributed to the activity of enzymes, such as lipases, lipoxygenase and acylhydrolases in whole oat flour [22]. The storage stability of whole oat flour and its acid number of fat was also affected by the storage temperature $\left(40^{\circ} \mathrm{C}\right)$ that led to the degradation of lipid.

However, the stages were different in case of flour mixture stored at $20^{\circ} \mathrm{C}$. Two stages can be identified here: the first stage (up to 105 days) was an induction period when the rates changed slightly and acid number of fat increased from 17.4 $\mathrm{mg}$ of $\mathrm{KOH} / 1 \mathrm{~g}$ of fat to $40 \mathrm{mg}$ after 105 days of storage respectively; the second stage was the development process 
(from 120 to 165 days) when an acid number of fat increased from $53 \mathrm{mg}$ of $\mathrm{KOH} / 1 \mathrm{~g}$ of fat to $73.5 \mathrm{mg}$ after 165 days of storage respectively. This indicates a decrease in the rate of fat degradation and a decrease in an acid number of fat under these storage conditions.

TABLE 1. EFFECT OF STORAGE CONDITIONS ON ACIDITY AND ACIDITY BY WATER-ALCOHOL EXTRACTION

\begin{tabular}{|c|c|c|c|c|c|c|c|c|}
\hline \multirow{3}{*}{$\begin{array}{c}\text { Storage } \\
\text { period } \\
\text { (days) }\end{array}$} & \multicolumn{8}{|c|}{ Storage samples } \\
\hline & \multicolumn{2}{|c|}{$\begin{array}{c}\text { Whole oat flour cloth } \\
\text { bags } 40^{\circ} \mathrm{C}\end{array}$} & \multicolumn{2}{|c|}{$\begin{array}{l}\text { Flour mixtures cloth bags } \\
20^{\circ} \mathrm{C}\end{array}$} & \multicolumn{2}{|c|}{$\begin{array}{c}\text { Flour mixtures plastic } \\
\text { bags } 40^{\circ} \mathrm{C}\end{array}$} & \multicolumn{2}{|c|}{$\begin{array}{l}\text { Flour mixtures cloth bags } \\
40^{\circ} \mathrm{C}\end{array}$} \\
\hline & Acidity $^{a}$ & $\begin{array}{c}\text { Acidity by } \\
\text { water-alcohol } \\
\text { extraction }^{b}\end{array}$ & Acidity $^{a}$ & $\begin{array}{c}\text { Acidity by } \\
\text { water-alcohol } \\
\text { extraction }^{b}\end{array}$ & Acidity $^{a}$ & $\begin{array}{c}\text { Acidity by } \\
\text { water-alcohol } \\
\text { extraction }^{b}\end{array}$ & Acidity $^{a}$ & $\begin{array}{c}\text { Acidity by } \\
\text { water-alcohol } \\
\text { extraction }^{b}\end{array}$ \\
\hline Zero time & 3.1 & 2.0 & 3.9 & 2.5 & 3.9 & 2.5 & 3.9 & 2.5 \\
\hline 15 & 5.5 & 5.0 & 4.2 & 3.5 & 4.5 & 4.0 & 4.9 & 4.5 \\
\hline 30 & 5.7 & 5.5 & 4.6 & 4.0 & 5.1 & 4.5 & 5.6 & 5.0 \\
\hline 45 & 6.1 & 5.5 & 5.1 & 4.5 & 5.6 & 5.0 & 5.9 & 5.5 \\
\hline 60 & 6.2 & 5.9 & 5.2 & 4.9 & 5.7 & 5.5 & 6.0 & 5.5 \\
\hline 75 & 6.3 & 6.0 & 5.4 & 5.0 & 5.8 & 5.7 & 6.1 & 5.9 \\
\hline 90 & 6.5 & 6.0 & 5.7 & 5.4 & 6.0 & 6.0 & 6.3 & 6.4 \\
\hline 105 & 6.8 & 6.5 & 6.2 & 6.1 & 6.4 & 6.6 & 6.4 & 6.8 \\
\hline 120 & 7.5 & 7.5 & 6.4 & 6.3 & 6.7 & 7.0 & 6.9 & 7.1 \\
\hline 135 & 8.0 & 7.7 & 6.5 & 6.2 & 7.1 & 7.1 & 7.5 & 7.4 \\
\hline 150 & 8.9 & 8.2 & 7.0 & 7.0 & 7.3 & 7.2 & 7.7 & 7.5 \\
\hline 165 & 9.8 & 10.5 & 8.1 & 7.5 & 8.5 & 8.2 & 8.6 & 9.2 \\
\hline
\end{tabular}

a. Degree of acidity.

b. Acidity degree by water-alcohol extraction.

Furthermore, the results showed that the addition of fenugreek seed powder to flour mixture significantly decreases the rate of increase of an acid number of fat when using both types of bags (cloth and plastic). This bioactive effect of fenugreek seed powder causes longer preservation of flour mixture without oxidation and degradation of the lipids compounds as compared to the whole oat flour stored at the same temperature $\left(40^{\circ} \mathrm{C}\right)$. It stems from the fact that the fenugreek seed powder contains flavonoids, such as isovitexin and vitexin that have the antioxidant effect [23]. However, the antioxidant effect lasted only until the $135^{\text {th }}$ day of storage. Then acid number of fat increased due to the deterioration of flavonoid compounds in the fenugreek seed stored at high temperature $\left(40^{\circ} \mathrm{C}\right)$ for a long period of time.

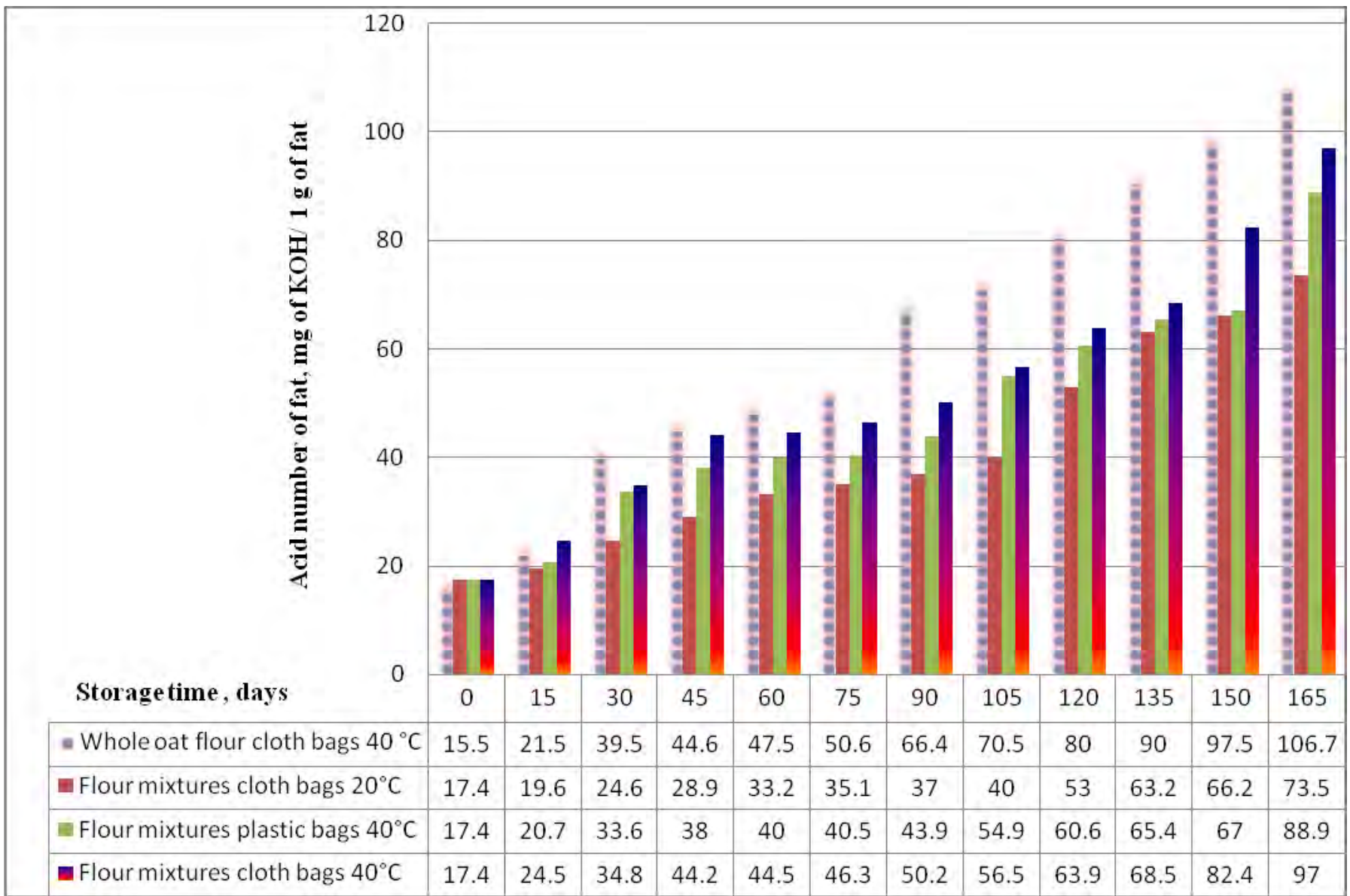

Fig. 3. Effect of storage conditions on acid number of fat 
The results showed that on the one hand, the type of storage bags (cloth or plastic) did not produce a significant effect on the acid number of fats in flour mixtures stored at $40^{\circ} \mathrm{C}$ for the antioxidant effect of fenugreek seed powder. We did not observe significant high oxidation effect on flour mixture stored in the cloth bags until the $75^{\text {th }}$ day of storage. However, the increase in the storage period at high temperature led to the degradation of flavonoid compounds (antioxidants).

Therefore, the type of bags had a strong effect on acid number of fat. It was recorded that the rate of increase in fat acidity was higher in cloth bags as compared to samples stored in plastic bags. The obtained result may be attributed to the ability of plastic bags to isolate the air streams and reduce the lipid oxidation.

\section{Microbiological Load}

Fig. 4 illustrates the total bacterial count in whole oat flour stored in cloth bags and in flour mixtures with fenugreek seed powder stored at 20 and $40^{\circ} \mathrm{C}$ in cloth and plastic bags. According to the results, the initial storage period showed no significant difference between the bacterial count in whole oat flour obtained by hydrothermal treatment and flour mixture. In addition, fungi growth was not recorded in this study.
Absence of fungi growth in both whole oat flour and flour mixture arises from the thermal treatment and vacuum treatment used to obtain whole flour by hydrothermal treatment and killing the fungi as well as the addition of fenugreek seed powder in flour mixture with its inhibitory effect on fungi growth.

The results showed that in case of whole flour mixtures stored at $40^{\circ} \mathrm{C}$ in cloth bags the bacterial count increased in the first period of storage (until 30 days). Still, in the later stages the bacterial count minimized because the acidity of whole oat flour increased and inhibited bacterial growth [24].

The study found out that the bacterial count in all flour mixture samples with fenugreek seed powder decreased since fenugreek shows antifungal and antibacterial activity [25].

However, the bacterial count slightly decreased in flour mixture stored at $20^{\circ} \mathrm{C}$ as compared to flour mixtures stored at $40^{\circ} \mathrm{C}$. These results correspond to the results of acidity measurement when the acidity level of samples stored at $40^{\circ} \mathrm{C}$ increased more than that of the mixture stored at $20^{\circ} \mathrm{C}$. On the other hand, the type of bags showed no significant difference in bacterial growth rate.

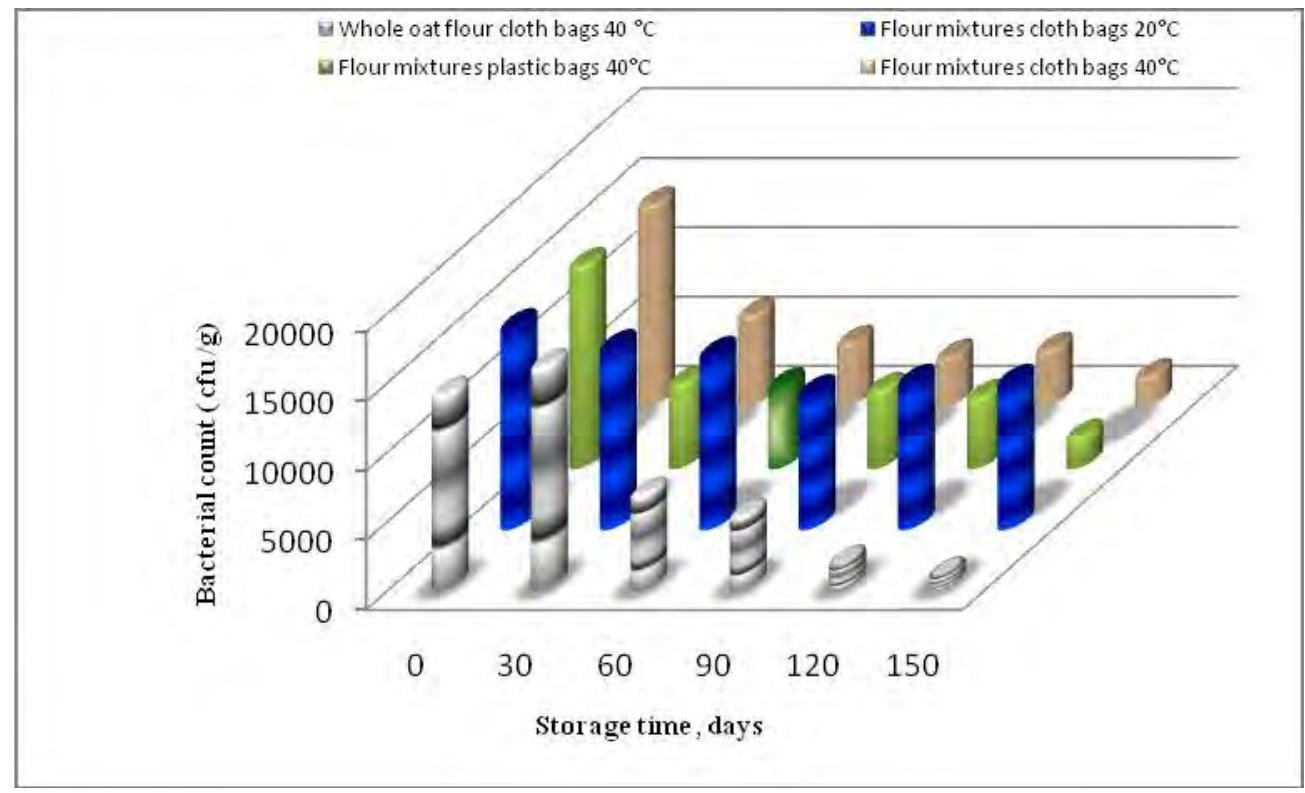

Fig. 4. Effect of storage conditions on microbiological load

\section{CONCLUSION}

This study demonstrates factors that affect shelf stability of whole oat flour and flour mixture, namely storage temperature, bags type, fenugreek seed powder addition, and its importance in extending the shelf life of flour mixture. The stability of flour mixture significantly increased with the addition of fenugreek seed powder at 20 and $40^{\circ} \mathrm{C}$. The increase in acid number of fat was lower in flour mixture than in the whole oat flour at the same storage temperature because the oxidation activity causing rancidity was inhibited by antioxidant compounds in fenugreek seed powder. The study found out that the bacterial count in all flour mixture samples containing fenugreek seed powder decreased since fenugreek showed antifungal and antibacterial activity. According to the research, fenugreek seed powder might be of critical importance in extending the storage period of flour mixture. 


\section{References}

[1] J.T. Braaten, P.D. Wood, F.W. Scott, M.S. Wol-ynetz, M.K. Lowe, P. Bradley-White and M.W. Collins, "Oat B-glucan reduces blood cholesterol concentration in hypercholesterolemia," Eur. J. Clin. Nutr., vol.48, pp. 465-474, 1994.

[2] B. D.Sanju and S.S. Kawaljit, "Wheat-Fenugreek Composite Flour Noodles: Effect on Functional, Pasting, Cooking and Sensory Properties," Current Research in Nutrition and Food Science, vol. 6(1), pp.174-182, 2018.

[3] H.Shalini and J. Sudesh, "Organoleptic and nutritional evaluation of biscuits supplemented with untreated and treated fenugreek flour," Food Chemistry,vol. 90(3), pp. 427-435, 2005.

[4] K. Srinivasan, "Fenugreek (Trigonella foenum-graecum): A Review of Health Beneficial Physiological Effects," Food Review International, Vol. 22 (2), pp. 203-224, 2006.

[5] L.V. Anisimova and O.I.A. Soltan, "Rheological properties of dough from wheat flour and whole oat flour," Polzunovsky vestnik, vol. 3, pp. 913, 2017.

[6] V.A. Gunkinand, G.M. Suslianok, "Preparation off lakes from the shellgrain oats grains,"Khleboproducty, vol. 9, pp. 62-63, 2016.

[7] T.A. Nikiforova and I.A. Hon, "Integrated use of secondary raw materials for cereals," Khleboproducty, vol. 5, pp. 50-51, 2014

[8] R.L. Heiniö, P. Lehtinen, K.M. Oksman-Caldentey and K. Poutanen"Differences Between Sensory Profiles and Development of Rancidity During Long-Term Storage of Native and Processed Oat," Cereal Chemistry, vol. 79 (3), pp. 367-375, 2002.

[9] P. Lehtinen, K. Kiiliainen, I. Lehtomaki and S. Laakso, "Effect of heat treatment on lipid stability in processed oats," J. of Cereal Science, Vol. 37(2), pp. 215-221, 2003.

[10] H. Dagmara, C. Stefan, A. Susan and H. Kelly "Storage stability of oat groats processed commercially and with superheated steam," Food Science and Technology, vol. 44, pp. 261-268, 2011.

[11] ICMSF, Microorganisms in Foods: 6 Microbial Ecology of Food Commodities. Blackie Academic and Professional, London, pp. 313-346, 1998.

[12] GOST standards, 9404-88 Flour, Method for determination of moisture, Moscow, pp. 8, 2009.

[13] GOST standards, 27493-87 Flour and bran, Method for the determination of acidity, Moscow, pp. 4, 2007

[14] A.V. Myasnikova and Y.S. Rall, The Workshop on Commodity Grain and Products of Its Processing: Kolos, pp. 320, 1981
[15] GOST Standards, 31700-2012, Grain and products of its processing. Method for determining the acid number of fat, p. 12, 2013.

[16] E.A. Amankwah, J. Barimah, A.K.M. Nuamah, J.H. Oldham, and C.O Nnaji, "Formulation of weaningfood from fermented maize, rice, soybean and fishmeal," Pak. J. Nutr, vol. 8, pp.1747-1752, 2009.

[17] H. Dagmara, C. Stefan, A. Susan and H. Kelly, "Storage stability of oat groats processed commercially and with superheated steam," Food Science and Technology, vol.(44), pp. 261-268,2011.

[18] K.T. Roberts, S.W. Cui, Y.H. Chang, P.K.W. Ng and T. Graham,"The influence of fenugreek gum and extrusion modified fenugreek gum on bread," Food Hydrocolloids, vol. 26,pp. 350-358, 2012.

[19] T. Rehman, M. Sharif, M. Majeed, M.U. Khan, M.A. Shariati and V. Hristova, "Effect of nutritional composition on shelf life of cereals legumes blended flours during storage," J. of microbiology, biotechnology and food sciences, vol. 6(4), pp. 1112-1116, 2017 .

[20] A.I. Hegazy, "Influence of Using Fenugreek Seed Flour as Antioxidant and Antimicrobial Agent in the Manufacturing of Beef Burger with Emphasis on Frozen Storage Stability," World J. of Agricultural Sciences, vol. 7 (4), pp. 391-399, 2011.

[21] L.V. Anisimova and O.I.A. Soltan, "Storage stability of oat flour were producted with different methods," Polzunovsky vestnik, vol. 4, pp.14-20, 2017.

[22] E.L. Molteberg, G. Vogt, A. Nilsson and W. Frolich, "Effects of Storage and Heat Processing on the Contentand Composition of Free Fatty Acids in Oats," Cereal Chem., vol. 72(1), pp. 88-93, 1995.

[23] P.S.Chaubey, G.Somani, D.Kanchan,S.Sathaye, S.Varakumar and R.S Singhal, "Evaluation of debitteredand germinated fenugreek (Trigonella foenum graecum $L$.) seedflour on the chemical characteristics, biological activities, andsensory profile of fortified bread," J. Food Process Preserv., vol. 42, e13395, 2018. https://doi.org/10.1111/jfpp.13395

[24] L.K.Berghofer, A.D. Hocking, D. Miskelly and E. Jansson, "Microbiology of wheat and flour milling in Australia," Int. J. Food Microbiology, vol.85, pp.137-149, 2003.

[25] S.A. Wani and P. Kumar, "Fenugreek: A review on its nutraceutical properties and utilization in various food products," J. of the Saudi Society of Agricultural Sciences, vol. 17, pp. 97-106, 2018. 